\title{
Detection of Toxoplasma gondii in small ruminants in Chennai using PCR and modified direct agglutination test
}

\author{
Ajay Suryakant Satbige ${ }^{1}\left(\mathbb{D} \cdot\right.$ M. Vijaya Bharathi ${ }^{2} \cdot$ P. I. Ganesan ${ }^{2} \cdot$ \\ C. Sreekumar ${ }^{3}$ C. Rajendran ${ }^{4}$
}

Received: 11 June 2015/Accepted: 31 August 2015/Published online: 13 January 2016

(C) Indian Society for Parasitology 2016

\begin{abstract}
A total of 193 sera samples, along with tissues (lung, heart, and brain) collected from 136 sheep and 57 goats from the Corporation slaughter house, Madras Veterinary College teaching hospital, and private mutton shops from Chennai were tested for Toxoplasma gondii. All the sera samples were tested using modified direct agglutination test. Of the 193 sera samples, $57(29.5 \%)$ had a minimum titre of $1: 20$, with $30.14 \%$ (41/136) of sheep and $28.07 \%(16 / 57)$ of goats being seropositive. Tissue samples from all 193 animals, when subjected to B1 based PCR to detect $T$. gondii DNA, showed 3.67 and $3.50 \%$ to be positive in sheep and goats, respectively. In the present investigation B1 based PCR detected T. gondii in low numbers, possibly due to limitation of the sample size. The presence of $T$. gondii in tissues of sheep and goats slaughtered for human consumption in Chennai indicates the role of these food animals as potential sources of infection to human.
\end{abstract}

A part of master thesis submitted to the Madras Veterinary College (TANUVAS), Vepery, Chennai-600 007, Tamilnadu, India.

Ajay Suryakant Satbige

dr.ajaysatbige@gmail.com

M. Vijaya Bharathi

mvijayabharathi74@gmail.com

1 Department of Veterinary Medicine, Veterinary College, KVAFSU, Bidar 585401, India

2 Department of Veterinary Epidemiology and Preventive Medicine, Madras Veterinary College, Vepery, Chennai, Tamilnadu 600 007, India

3 PGRIAS, TANUVAS, Kattupakkam, Chennai 600056, India

4 Defence Food Research Laboratory, Defence Research and Development Organisation (DRDO), Siddarthanagar, Mysore, Karnataka 570 011, India
Keywords Toxoplasma gondii .

Modified direct agglutination test - B1 PCR .

Sheep and goats

\section{Introduction}

Toxoplasmosis is a worldwide (pandemic) zoonotic disease caused by Toxoplasma gondii, an obligate intracellular protozoan parasite, which infects all warm blooded animals including human beings. Cats and other felids are the definitive hosts of the parasite (Garcia et al. 1999). The prevalence of toxopalsmosis in animals varies from country to country. As far as animal toxoplasmosis is concerned, the incidence in various economically important livestock species is highly variable (Dubey and Beattie 1988) with documented evidence of global prevalence rates as high as $28.9 \%$ in goats (Gondim et al. 1999), $38.5 \%$ in sheep (Freyre et al. 1997), $66 \%$ in cattle (Eren et al. 1997). In small ruminants, toxoplasmosis is one of the infectious causes of reproductive failure (Owen et al. 1998). Rearing of sheep and goats plays a major role in the farming community and fetal loss is a serious problem in small ruminants. Further, most of the farmers rear sheep and goats in free range or in semi-intensive system in India. So the possibility of ingestion of oocysts by these grazing ruminants is also high. Mutton and chevon are very important sources of protein in India and thus, sheep and goats can act as potential modes of transmission of $T$. gondii to humans. Transmission of $T$. gondii through goat milk had also been documented (Sacks et al. 1982). Traditionally, various serological methods have been used for the detection $T$. gondii antibodies in domestic animals and human beings. Molecular methods are also routinely used 
in the diagnosis of toxoplasmosis. The present study focussed on diagnosis of $T$. gondii infection in ruminants based on PCR and modified direct agglutination tests.

\section{Materials and methods}

Modified direct agglutination test (MAT) antigen and reference sera (positive and negative) were kindly provided by Department of Laboratory Medicine, AIIMS, New Delhi. Primers for B1gene (Angel et al. 1997) was obtained from Eurofins Genomics, Bangalore. PCR master mix $(2 \times)$ was obtained from Ampliqon and stored at $-20^{\circ} \mathrm{C} .100 \mathrm{bp}$ DNA molecular size marker was obtained from Gene ruler, Thermo Scientific, Fermentas. DNeasy Tissue extraction kit (QIAGEN, Germany) was used to extract DNA from tissue samples. Proteinase $\mathrm{K}$ solution was procured from Himedia, (20 mg/ml, W/V).

Serum, along with tissues samples were collected from sheep (136) and goats (57) as follows: Whole blood (5 ml) and samples of heart, brain, lungs and placenta (up to $50 \mathrm{~g}$ ) were collected from sheep and goats from the Corporation slaughter house, Perambur and private mutton shops. Blood and tissues samples were collected from cases of abortion brought to Madras Veterinary College teaching hospital. The blood samples were allowed to clot and centrifuged at $2500 \mathrm{rpm}$ and the clear serum was transferred to sterile $2 \mathrm{ml}$ storage vial. These serum samples were stored at $-20{ }^{\circ} \mathrm{C}$ until further use. All tissue samples were stored at $4{ }^{\circ} \mathrm{C}$ until further study.

MAT was performed with minor modification as per the procedure of Desmonts and Remington (1980). A minimum titre of 1:25 was considered as positive in MAT in sheep and goat (Dubey et al. 2008).

\section{Extraction of genomic DNA}

All 193 tissue samples were subjected to B1 based PCR to detect $T$. gondii. DNA extraction was carried out from pooled samples of heart, lung, and brain using DNeasy Tissue Kit as per the manufacturer's instructions. The extracted DNA was stored in aliquots at $-20{ }^{\circ} \mathrm{C}$.

\section{Polymerase chain reaction $(\mathrm{PCR})$}

PCR assay targeted to B1 gene (194 bp) was used for diagnosis of toxoplasmosis as per Angel et al. (1997). The nucleotide sequences of the forward and reverse primers are as follows for B1 gene (194 bp size).

Forward: 5'-GGA ACT GCA TCC GTT CAT GAG-3' and

Reverse 5': TCT TTA AAG CGT TCG TGG TC-3'
PCR amplification of B1 gene fragment was setup in $25 \mu \mathrm{l}$ reactions. The reaction mixture consisted of $4.0 \mu \mathrm{l}$ $(58 \mathrm{ng}$ ) of template DNA, $12.5 \mu \mathrm{l}$ of $2 \times$ master mix which consist of $10 \times$ PCR buffer, $10 \mathrm{mM}$ dNTP mix, and Taq DNA polymerase and $1.0 \mu \mathrm{l}$ each $(10 \mathrm{pmol})$ of the forward and the reverse primer. The volume was made up to $25 \mu \mathrm{l}$ by nuclease free water $(6.5 \mu \mathrm{l})$. The cycling conditions were as follows; the first series of thermal cycling (prePCR) consisted of initial denaturation at $94{ }^{\circ} \mathrm{C}$ for $5 \mathrm{~min}$, followed by 30 cycles of denaturation $94{ }^{\circ} \mathrm{C}$ for $45 \mathrm{~s}$ annealing at $60{ }^{\circ} \mathrm{C}$ for $1 \mathrm{~min}$ and extension at $72{ }^{\circ} \mathrm{C}$ for $2 \mathrm{~min}$. Final extension was performed at $72{ }^{\circ} \mathrm{C}$ for $10 \mathrm{~min}$. The PCR products $(5 \mu \mathrm{l})$ were loaded into the respective wells. Molecular weight marker (100 bp) and positive and negative controls were also run. The electrophoresis was carried out at $100 \mathrm{~V}$ for $45 \mathrm{~min}$ or until the tracking red dye migrated more than two third of the length of the gel tray. The gel was placed under UV trans-illuminator and the results were documented in a gel documentation system (Bio rad) to analyze and document the results.

\section{Results}

\section{Modified direct agglutination test}

A minimum titre of 1:20 was considered as positive in MAT. Of the 193 sera samples screened for the presence of antibodies against $T$. gondii, $57(29.5 \%)$ had a minimum titre of 1:20. Of the 57 seropositive samples, $30.14 \%$ (41/ 136) of sheep and $28.07 \%$ (16/57) of goats were found positive.

B1 based PCR: PCR revealed amplification of target fragment from five sheep samples $(3.67 \%)$ and two $(3.50 \%)$ goat samples Fig. 1.

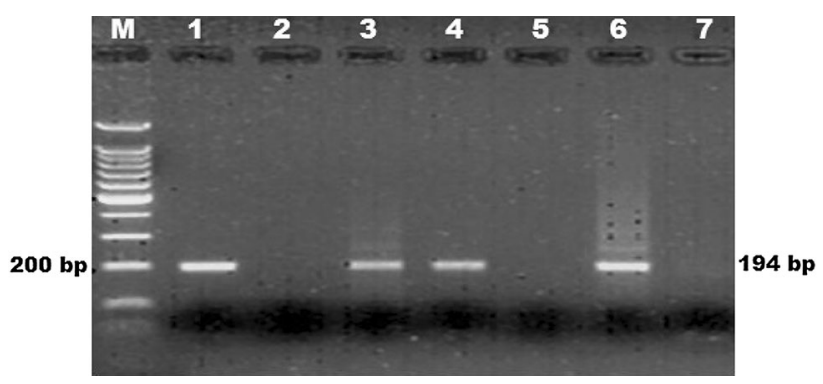

Fig. 1 B1 based PCR for detection of Toxoplasma gondii in small ruminants. $M$ molecular weight marker (100 bp ladder), 1 positive control, 2 negative control, 3, 4 sheep sample (heart, brain), 5, 6, 7 Goat sample (heart) 


\section{Discussion}

\section{Modified direct agglutination test}

Most of the earlier workers identified that MAT was the most sensitive test for toxoplasmosis. This study concurred with early works of Dubey and Thulliez (1989), Dubey et al. (1995), Gamble et al. (2005) and Vijaya Bharathi et al. $(2003,2011)$ and the above authors concluded that MAT was identified as most sensitive test than ELISA, IHAT and Latex agglutination test. Of the 136 sheep and 56 goat serum samples screened in this study for the presence of antibodies against $T$. gondii, 57 (29.5\%) were found positive, while Dubey and Adams (1990) and Mainar et al. (1996) reported a low seropositivity of 22.1 and $11.80 \%$ respectively. This prevalence study also agreed with Zhang et al. (1996), who reported that $32.9 \%$ goats were positive to $T$. gondii. Seroprevalence of $T$. gondii is highly variable and depends on many factors, the major one being the population density of the final host, the domestic cat. With a similar cut off value, Dubey and Kirkbride (1989) recorded a lesser titre of $22 \%$, while Patton et al. (1990) recorded a high seropositivity of $55-65 \%$.

\section{B1 based PCR diagnosis of $T$. gondii}

In this study, all 193 tissue samples were subjected to B1 based PCR to detect $T$. gondii. DNA extraction was carried out from pooled samples of heart, lung and brain based on the early works by Esteban-Redondo and Innes (1998). B1 gene based PCR applied on collected samples detected low number of samples. This study as concurred with early works of Hannah et al. (2013) in Chennai, who reported $14.25 \%$ to be positive by B1 PCR.

In the present study, 193 pooled tissue samples of sheep and goat were used for PCR for the detection of $T$. gondii. Among them seven (five sheep and two goat samples) were positive. In $T$. gondii, the 35-copy number B1gene is most widely used for diagnosis (Burg et al. 1989). The B1 gene found to be highly specific for $T$. gondii and well conserved among all the strains tested so far. The assay was sensitive for Toxoplasma detection from various clinical specimens such as blood, broncho-alveolar lavage, cerebrospinal fluid, urine, vitreous, lymph node, cerebrum and retina. A nested PCR assay targeting a B1 gene amplicon has been described to increase the detection levels and yield of the products (Pelloux et al. 1998). In the present investigation, less number of positive cases might be due to limitation of the sample size, as parasite may be present in the unexamined tissues.

This results of the study concurred with Esteban-Redondo et al. (1999) and Wyss et al. (2000) who concluded that serodiagnostic tests (ELISA) detected more positive $(79 \%)$ than PCR (6 \%). They also concluded that detection of parasite in food animals was very difficult due to the low density of the organisms.

This study detected $T$. gondii in tissues of sheep and goats slaughtered for human consumption in Chennai, which indicates the role of these species as a potential source of infection to human. In another study by Wastling et al. (1994), Jones et al. (2000) and Sreekumar (2001) compared the P30 and B1 gene based PCR diagnosis and concluded that PCR for B1 was superior to P30.

Acknowledgments Authors sincerely thank the Dean, Madras Veterinary College, Chennai (TANUVAS) for necessary help and guidance during the research work for the master degree programme.

\section{References}

Angel SO, Matrajt M, Margarit J, Nigro M, Illescas E, Pszenny V, Amendoeira MR, Guarnera E, Garberi JC (1997) Screening for active toxoplasmosis in patients by DNA hybridization with the ABGTg7 probe in blood samples. J Clin Microbiol 35(3):591-595

Burg JL, Grover CM, Pouletty P, Boothroyd JC (1989) Direct and sensitive detection of a pathogenic protozoan, Toxoplasma gondii, by polymerase chain reaction. J Clin Microbiol 27:1787-1792

Desmonts G, Remington JS (1980) Direct agglutination test for diagnosis of Toxoplasma infection: method for increasing sensitivity and specificity. J Clin Microbiol 11:562

Dubey JP, Adams DS (1990) Prevalence of Toxoplasma gondii antibodies in dairy goats from 1982 to 1984. J Am Vet Med Assoc 1990:295-296

Dubey JP, Beattie CP (1988) Toxoplasmosis of animals and man. CRC Press, Boca Raton

Dubey JP, Kirkbride CA (1989) Enzootic toxoplasmosis in sheep in north-central United-States. J Parasitol 75:673-676

Dubey JP, Thulliez P (1989) Serologic diagnosis of toxoplasmosis in cats fed Toxoplasma gondii tissue cysts. J Am Vet Med Assoc 194(9):1297-1299

Dubey JP, Thulliez P, Weigel RM, Andrews CD, Lind P, Powell EC (1995) Sensitivity and specificity of various serologic tests for detection of Toxoplasma gondii infection in naturally infected sows. Am J Vet Res 56:1030-1036

Dubey JP, Sundar N, Hill D, Velmurugan GV, Bandini LA, Kwok OCH, Majumdar D, Su C (2008) High prevalence and abundant atypical genotypes of Toxoplasma gondii isolated from lambs destined for human consumption in the USA. Int J Parasitol 38:999-1006

Eren H, Babur C, Erdal N, Sert H (1997) The prevalence of Toxoplasma gondii in cattle in Ankara and Aydin by the SabinFeldman test. Turk Hij Deneysel Biyol Derg 54:31-34

Esteban-Redondo I, Innes EA (1998) Detection of Toxoplasma gondii in tissues of sheep orally challenged with different doses of oocysts. Int J Parasitol 28(9):1459-1466

Esteban-Redondo I, Maley SW, Thomson K, Nicoll S, Wright S, Buxton D, Innes EA (1999) Detection of $T$. gondii in tissues of sheep and cattle following oral infection. Vet Parasitol 86:155-171

Freyre A, Bonino J, Falcon J, Castells D, Correas O, Casaretto A (1997) The incidence and economic significance of ovine toxoplasmosis in Uruguay. Vet Parasitol 73:13-15 
Gamble HR, Dubey JP, Lambillotte DN (2005) Comparison of a commercial ELISA with the modified agglutination test for detection of Toxoplasma infection in the domestic pig. Vet Parasitol 128:177-181

Garcia JL, Navarro IT, Ogawa L, De-Oliveria RC (1999) Seroprevalence of Toxoplasma gondii in swine, cattle, sheep, band horses and their correlation with humans, cat and dogs, from farms in the north of Parana state, Brazil. Ciencia Rural 29:91-97

Gondim LFP, Jr HV, Barbosa CHA Riberiro-Filho, Saeki H (1999) Serological survey of antibodies to Toxoplasma gondii in goats, sheep, cattle and water buffaloes in Bahia State, Brazil. Vet Parasitol 82:273-276

Hannah V, Vijaya Bharathi M, Rajendran C, Shankar S, Senthil NR, Sathyabama K, Ganesan PI (2013) Detection of Toxoplasma gondii infection from the food animals by B1 gene based polymerase chain reaction. (International conference proceedings cited VPVGFS, PLAFFS, TANUVAS, and Chennai. p 177)

Jones CD, Okhravi N, Adamson P, Tasker S, Lightman S (2000) Comparison of PCR detection methods for B1, P30 and 18S rDNA genes of Toxoplasma gondii in aqueous humor. Investig Opthalmol 41:634-644

Mainar RC, de la Cruz C, Asensio A, Dominguez L, Vazquez-Boland JA (1996) Prevalence of agglutinating antibodies to Toxoplasma gondii in small ruminants of the Madrid region, Spain and identification of factors influencing seropositivity by multivariate analysis. Vet Res Commun 20:153-159

Owen MR, Clarkson MJ, Trees AJ (1998) Acute phase Toxoplasma abortions in sheep. Vet Rec 142:480-482

Patton S, Johnson SS, Puckett K (1990) Prevalence of Toxoplasma gondii antibodies in nine populations of dairy goats: compared titres using modified direct agglutination and indirect haemagglutination. J Parasitol 76:74-77
Pelloux H, Brun E, Vernet G, Marcillat S, Jolivet M, Guergour D, Fricker-Hidalgo H, Goullier-Fleuret A, Ambroise-Thomas $\mathrm{P}$ (1998) Determination of anti-Toxoplasma gondii immunoglobulin $G$ avidity: adaptation to the Vidas system (bioMérieux). Diagn Microbiol Infect Dis 32(2):69-73

Sacks JJ, Roberto RR, Brooks NF (1982) Toxoplasma infection associated with raw goat's milk. J Am Med Assoc 248:1728-1732

Sreekumar C (2001) PCR based diagnosis and genotyping of Toxoplasma gondii. Thesis, Ph.D. Deemed University, IVRI, Izatnagar and UP India

Vijaya Bharathi M, Mohamed Basheer A, Nedunchezhiyan S, Sarman Singh, Meenachi Selvan MS (2003) Comparison of modified direct agglutination and indirect haemagglutination tests for detection of Toxoplasma gondii antibodies in goats in Chennai. J Vet Parasitol 17:49-51

Vijaya Bharathi M, Kandavel E, Nedunchelliyan S, Muralimanohar B, Kumanan K (2011) Prevalence of Toxoplasma antibodies by using modified direct agglutination test in dogs in Chennai. J Vet Parasitol 25(2):162-164

Wastling JM, Harkins D, Buxton D (1994) Western blot analysis of the IgG response of sheep vaccinated with S48 Toxoplasma gondii (toxovax). Res Vet Sci 57:384-386

Wyss R, Sager H, Müller N, Inderbitzin F, König M, Audigé L, Gottstein B (2000) The occurrence of Toxoplasma gondii and Neospora caninum as regards meat hygiene. Schweiz Arch Tierheilkd 142:95-108

Zhang DL, Ma JW, Du CB, Li HP, Nu ZW, Wang YD, Li FX (1996) Serological determination of toxoplasmosis in sheep and goats in some villages and towns of Tianzhu, Gansu. Chin J Vet Sci Tech $26: 31$ 